\title{
Major Nutritional Issues in Deciduous Fruit Orchards of Northern Italy
}

Massimo Tagliavini ${ }^{1}$ and Bruno Marangoni

Additional INDEX wORds. fertilization, integrated fruit production, iron chlorosis, nitrogen, soil testing

Summary. Most deciduous fruit crops in Italy are grown in the north and especially in the eastern part of the Po River Valley (mainly in the Emilia Romagna and Veneto regions) and in the Adige River Valley (South Tyrol and Trento provinces). Soils in the wide Po River Valley, where pear (Pyrus communis), peach and nectarine (Prunus persica), kiwifruit (Actinidia deliciosa), plum (Prunus domestica and P. insititia), apricot (Prunus armeniaca), cherry (Prunus avium), and apple (Malus domestica) are grown, are alluvial, generally fertile, fine textured, alkaline, often calcareous and well enriched with Ca. Apple plantings are concentrated in the Adige Valley and located on a variety of soil types, including sandy loam, loamy sand soils or sandy clay, sometimes calcareous. Integrated fruit production is gaining importance and represents more than $80 \%$ of apple production in South Tyrol and about $60 \%$ of peach and nectarine production in Emilia Romagna. Under these conditions, the main objectives of mineral nutrition are to reconcile production and environmental concerns (minimize nutrient leaching, soil pollution, volatile emissions). In particular, fertilization aims to improve external and internal fruit quality and storage ability, reduce production costs, maintain soil fertility, avoid nutrient deficiency and excess and control tree vigor. Nitrogen applications have strongly decreased in recent years and there is a need to improve the efficiency of $\mathrm{N}$ fertilizers while avoiding deficiencies. Research is focussing on application technology, timing of $\mathbf{N}$ uptake, internal cycling of $\mathrm{N}$ and methods for assessing the need for $\mathrm{N}$ application (e.g., using estimates of native soil $\mathrm{N}$ availability). Early diagnosis of bitter pit is recommended for guiding applications of Ca sprays. Iron deficiency and chlorosis is a major problem in pear, peach and kiwifruit grown in alkaline and calcareous soils and Fe chelates are usually applied annually to the soil or to the canopy. Current research is focused on agronomic means for controlling the problem and on developing rootstocks tolerant to Fe deficiency.

I taly, with more than 2.5 million ha (6.2 millions acres) of plantings (Sansavini, 1998), is a major producer of fruit trees and grapes (Vitis sp.), especially if we take into account its relatively small size. Due to the presence of two separate climatic conditions, mediterranean and temperate, both evergreen and deciduous fruit crops are cultivated; while citrus (Citrus sp.) and olive (Olea europaea) are mainly located, with few exceptions, in the central and southern part of Italy, in the northern part of Italy is located a significant fraction of total deciduous fruit tree and wine grape production (Table 1 ).

\footnotetext{
Dipartimento di Colture Arboree, University of Bologna, Italy, Via Filippo Re 6, 40126 Bologna.

We acknowledge the valuable contribution of M. Toselli, A. D. Rombolà, M. Quartieri, C. Zavalloni, D. Malaguti, F. Mazzanti, P. Lucchi, and G. Sorrenti in research projects on mineral nutrition carried out in our laboratory. We are also grateful to W. Drahorad, O. Failla and D. Porro for useful information on soil conditions and specific management techniques in apple orchards in the Adige Valley. We thank D. Scudellari for his continuous ability to bring grower needs to our attention and to convert research results into practice. Dipartimento di Colture Arboree University of Bologna paper 1678. The research referred to in this paper was mainly founded by Regione Emilia Romagna, through Centro Ricerche Produzioni Vegetali (CRPV).

${ }^{1}$ Corresponding author: mtaglia@agrsci.unibo.it.
} 
The apple industry is mainly concentrated in the Trentino alto Adige region, and most of the production of pears, kiwifruit, peach and nectarine, plums, cherries and apricots in northern Italy is located in the central and eastern part of the Po Valley and especially in the plains of the Emilia Romagna region.

A current trend in fruit tree management is to consider mineral nutrition as a major tool for optimizing fruit yield and quality. This feeling also is present at the grower and field advisor levels. Local governments, in line with European Union policy, have been pushing for the adoption of sustainable ways to fertilize orchards. In general, apple and pear orchard systems are planted at higher densities and are more intensively managed than stone fruits. In modern orchards, pome fruit trees are grafted on dwarf rootstocks ['Malling 9' (M.9) for apple, quince (Cydonia oblonga) for pear] and are frequently irrigated while orchard alleys are usually grassed with weed control achieved by in row herbicide use. Although excessive vegetative growth is often a problem in stone fruits, they are usually grafted on medium to high vigor rootstocks (e.g., 'GF 677' for peach and nectarine; Sansavini et al., 1999). Soil orchard floor management in stone fruit orchards is obtained by tillage of tree strips and maintenance of grassed alleys if irrigation is available, or by total cultivation of the soil surface if trees are still young or if no irrigation is available.

The aim of this paper is to provide a review of the current trends in mineral fertilization of deciduous fruit trees in Italy and the main goals of research in this area.

\section{Soil characteristics}

The eastern Po Valley (EmiliaRomagna region) is an area of about $10,000 \mathrm{~km}^{2}\left(3,860 \mathrm{mile}^{2}\right)$ of alluvial soils derived from sediments of the Po River, sometimes mixed with sediments from the Appennini Mountains (southern border). Orchard soils are almost invariably deep, well endowed with clay and silt (loam to clay-loamy soils, with few sandy-loam soils) and have medium to high cation exchange capacity, often saturated with $\mathrm{Ca}>\mathrm{mag}$ nesium $(\mathrm{Mg})$-potassium $(\mathrm{K})>$ sodium $(\mathrm{Na})$. Soils are usually subalkaline to alkaline and calcium carbonate $\left(\mathrm{CaCO}_{3}\right)$ content varies from being almost absent to levels (up to $15 \%$ total $\mathrm{CaCO}_{3}$ ) that deeply affect mineral nutrition of trees, especially impairing Fe uptake. Soil organic matter content is usually low (Regione Emilia Romagna, 1994).

Most apple production in Italy is located in the Trentino alto Adige region and concentrated in the Adige Valley or in lateral mountain valleys, such as Val di Non, that has a worldwide recognition for high quality 'Golden Delicious' and 'Renetta' apples. South Tyrol, the upper Adige Valley, has about 18,000 ha $(44,500$ acres) of modern apple plantings mainly located (about 80\%) in sandy loam soils or loamy sand soils (clay $85 \%$ to $15 \%$ ), with $\mathrm{pH}$ ranging from 5.5 to 6.0, generally low in Ca but rich in humus content ( $3 \%$ to $4 \%$ ) as a result of widespread application of mulches, and, previously, of manure. These soils are poorly endowed with $\mathrm{Ca}$ and $\mathrm{pH}$ ranges between 5.5 to 6.5. (Drahorad, 1999). The remaining soils developed from dolomite sediments $(\mathrm{pH}=7$ to $8)$.

The southern part of Trentino alto Adige region, the Trento Province, has about 12,000 ha $(29,640$ acres) apples mainly on alluvial, sandy loam soils, with high water tables (Failla et al., 1993), and are neutral or slightly alkaline and well endowed with organic matter, phosphorous $(\mathrm{P})$ and $\mathrm{K}$. Plantings on mountain slopes are on sandy-clay, calcareous soils with high organic matter content.

\section{Climate characteristics}

The climate in north Italy is temperate-subcontinental, with cold winters (frost may occur 40 to $50 \mathrm{~d}$ per year) and hot summers; the average annual temperature is 12 to $14{ }^{\circ} \mathrm{C}$ $\left(53.6\right.$ to $\left.57.2^{\circ} \mathrm{F}\right)$, rainfall 600 to 800 $\mathrm{mm}$ ( 24 to 31 inches), and is mainly concentrated in spring and fall. Evapotranspiration is greater than precipitation during the growing season.

\section{Nutrient management under integrated fruit production}

Integrated fruit production has been largely adopted in orchards of north Italy. About $60 \%$ of peach and nectarine orchards in Emilia Romagna and $85 \%$ of apple orchards in South Tyrol follow the guidelines of integrated fruit production.

Correct nutrient supply under these conditions is expected to reconcile yields (including quality characteristics and storage issues) and environmental concerns (minimize leaching, soil pollution, volatile emissions). Growers feel that by fine tuning nutrient supply they may improve external and internal fruit quality, fruit storage life, lower production costs (by adopting more efficient supply methods), maintain or improve soil fertility and partially control tree vigor. The major obligations to be met under integrated fruit production in the principal fruit growing areas of northern Italy include annual soil and leaf analysis and upper limit to annual fertilizer applications.

\section{Fertilization programs}

Fertilization programs vary as a result of several factors: species, rootstocks, expected yields, soil chemical and physical conditions, and soil management. The presence of irrigation and the possibility of adding nu-

Table 1. Deciduous fruit and nut production area and yield in Italy, 1996 (from Sansavini, 1998).

\begin{tabular}{|c|c|c|c|}
\hline \multirow[b]{2}{*}{ Crop } & \multicolumn{2}{|c|}{ Area $(1,000 \text { ha })^{z}$} & \multirow{2}{*}{$\begin{array}{c}\text { Yield } \\
(\mathbf{1}, 000 t)^{\mathrm{y}}\end{array}$} \\
\hline & Total & Immature & \\
\hline Apple & 71.6 & 6.1 & 2071.2 \\
\hline Apricot & 16.5 & 2.1 & 137.7 \\
\hline Cherry & 28.6 & 2.1 & 145.4 \\
\hline Kiwifruit & 18.4 & 0.5 & 344.0 \\
\hline Peach & 73.0 & 5.9 & 1194.8 \\
\hline Nectarines & 33.6 & 4.5 & 559.2 \\
\hline Pear & 51.8 & 6.2 & 966.4 \\
\hline Plum & 13.8 & 1.5 & 181.1 \\
\hline Total & 307.3 & 28.9 & 5599.8 \\
\hline
\end{tabular}

${ }^{\mathrm{z}} 1,000$ ha $=2,471$ acres.

$\mathrm{y} 1,000 \mathrm{t}=1,102$ tons. 
trients to the irrigation water (by drip or microjets) has also a great impact on fertilization programs and especially on amounts, type of fertilizer, timing and frequency of application.

Nitrogen. Nitrogen application rates in orchards have been significantly reduced in the last 15 years, before which excessive rates, often exceeding $200 \mathrm{~kg} \cdot \mathrm{ha}^{-1}$ (178 lb/acre) of $\mathrm{N}$ were used. Standard recommendations for fertilization now suggest less then $60 \mathrm{~kg} \cdot \mathrm{ha}^{-1}$ ( $53 \mathrm{lb} /$ acre $)$ of $\mathrm{N}$ for pome fruits and $100 \mathrm{~kg} \cdot \mathrm{ha}^{-1}(89 \mathrm{lb} /$ acre) of $\mathrm{N}$ for peach. Clearly there is a need to enhance the efficiency of $\mathrm{N}$ fertilizers, improve application technology and fine tune $\mathrm{N}$ supplies to avoid the occurrence of $\mathrm{N}$ deficiency symptoms (Tagliavini et al., 1996b). As a result of the significant decrease in $\mathrm{N}$ rates, excessive vegetative growth, that reduced fruit quality, is less frequent than in the past.

Significant progress has resulted from improved knowledge of the key role of the internal cycling of $\mathrm{N}$ (Tagliavini et al., 1997 and 1998; Toselli et al., 2000) on fruit set the following year.

Main recommendations for $\mathrm{N}$ fertilization include the following.

1) Postponing spring $N$ supply until flowering or fruit set (when reliable estimates of current year yield can be made), with small amounts recommended at bud burst only when trees are still young, are grafted on dwarf rootstocks, are planted in infertile soils, or carried high yields the previous year.

2) Providing enough $\mathrm{N}$ to the roots throughout the season (often a second $\mathrm{N}$ application is required, e.g., in peach at the time of pit hardening), but avoiding excesses.

3) Favoring $N$ storage for remobilization the following year by adding limited amounts of $\mathrm{N}$ through the soil [ 20 to $40 \mathrm{~kg} \cdot \mathrm{ha}^{-1}$
(18 to $36 \mathrm{lb} / \mathrm{acre}$ )] or the canopy (single sprays of urea at $5 \%$ or $3 \%$ in pome and stone fruit, respectively) at the end of summer-early fall. Such late N supply is not recommended in fertile soils, when leaf diagnosis indicates high leaf $\mathrm{N}$ concentration in summer or when fruit yields are low and excessive shoot elongation growth has occurred.

Under most conditions, soil $\mathrm{N}$ fertilization is not advised after the end of September as it might increase the risk of nitrate leaching into the ground water and interfere with normal shoot hardening before winter frosts.

Several $\mathrm{N}$ fertilizer sources are used by growers; mainly ammonium nitrate, potassium nitrate, urea. Regardless of the form of $\mathrm{N}$ applied, the addition of mineral $\mathrm{N}$ fertilizers results in an increase only in the nitrate- $\mathrm{N}$ fraction in the soil solution (Tagliavini et al., 1995) that brings about a rhizosphere $\mathrm{pH}$ increase, due to plant absorption, with adverse effects on availability and uptake of some micronutrients.

Potassium. Potassium fertilization is usually recommended in several fruit crops, unless soil are very well endowed with $\mathrm{K}\left[>150 \mu \mathrm{g} \cdot \mathrm{g}^{-1}(\mathrm{ppm})\right.$ extractable $\mathrm{K}]$. The role of $\mathrm{K}$ has been underestimated for decades for at least two reasons: 1) the assumption that soil $\mathrm{K}$ availability in orchards, as measured by soil testing, was sufficiently high and 2) the poor response of trees following the addition of $\mathrm{K}$ fertilizers in a granular form by broadcast applications on the soil surface. Withdrawing $\mathrm{K}$ for decades from fertilization programs has caused the reoccurrence of symptoms of $\mathrm{K}$ deficiency in kiwifruit and grape (Tagliavini et al., 1996a) on soils rich in clay, that was overcome only by resaturating exchange sites with $\mathrm{K}$.

Efficient K supply in fine textured soils is not easy to achieve with con- ventional broadcast applications, although fertigation appears to be a promising technique for increasing $\mathrm{K}$ availability in the root zone. Peach and apple grown in the eastern part of the Po Valley benefit from efficient K supply [ 50 to $100 \mathrm{~kg} \cdot \mathrm{ha}^{-1}(44.5$ to $89 \mathrm{lb} /$ acre) of $\mathrm{K}]$ as evidenced by increased fruit size, sugar content and improved fruit color (Table 2) (Rombolà et al., 2000; Zavalloni et al., 1998). In apple, $\mathrm{K}$ is applied either during midstages of fruit development or, in soils rich in clay, at the end of the season. Single spring application of $\mathrm{K}$ is usually avoided because of potential adverse effects on $\mathrm{Ca}$ nutrition. Excessive $\mathrm{K}$ supply in pear and apple, suggested years ago by private advisors operating in northern Europe, did not cause further improvement in $\mathrm{K}$ nutrition but triggered the occurrence of $\mathrm{Mg}$ deficiency symptoms such as early leaf drop in summer.

Calcium. Calcium nutrition is a major concern for apple growers, especially for some cultivars (e.g., 'Braeburn', 'Red Delicious' and 'Renetta') in soils poorly endowed with $\mathrm{Ca}$, such as those of the South Tyrol and Trentino areas. The main goal of $\mathrm{Ca}$ applications is to reduce bitter pit, Jonathan spot, scald and to improve fruit storage life. While cultural practices, such as fruit thinning, reducing $\mathrm{K}$ and $\mathrm{N}$ applications, pruning and consistent watering are considered to be very important for optimizing fruit partitioning of root absorbed Ca, calcium fertilizers are mainly applied on the canopy in order to be directly taken up by fruits, thereby increasing the $\mathrm{Ca}$ concentration in outer fruit layers. Application of $\mathrm{Ca}$ sprays has been tested in other fruit crops such as peach, kiwifruit, and pears, with relatively inconsistent results (Scudellari et al., 1998a). However, Ca sprays applied to nectarine trees reduced the incidence of skin russeting, therefore

Table 2. Effect of the form of nutrient supply on potassium $(\mathrm{K})$ nutrition and fruit characteristics in two nectarine cultivars (from Zavalloni et al., 1998); $1 \mathrm{~g}=0.035 \mathrm{oz} ; 1 \mathrm{~kg}=2.2 \mathrm{lb}$.

\begin{tabular}{|c|c|c|c|c|c|c|}
\hline Treatment & \multicolumn{3}{|c|}{ 'Caldesi 84' } & \multicolumn{3}{|c|}{ 'Caldesi 2000' } \\
\hline Unfertilized control & $120 b^{z}$ & $72 \mathrm{a}$ & $1.35 \mathrm{~b}$ & $128 \mathrm{c}$ & $27 \mathrm{c}$ & $1.60 \mathrm{c}$ \\
\hline $\mathrm{N}-\mathrm{P}-\mathrm{K}$ in granular form & $125 \mathrm{ab}$ & $62 \mathrm{~b}$ & $1.42 \mathrm{~b}$ & $146 \mathrm{~b}$ & $28.5 \mathrm{~b}$ & $1.84 \mathrm{~b}$ \\
\hline $\mathrm{N}-\mathrm{P}-\mathrm{K}$ by fertigation & $131 \mathrm{a}$ & $77 \mathrm{a}$ & $1.55 \mathrm{a}$ & $163 \mathrm{a}$ & $31.2 \mathrm{a}$ & $1.90 \mathrm{a}$ \\
\hline
\end{tabular}

${ }^{\mathrm{z}}$ Mean separation within column by Duncan test $(P=0.05)$. 
Table 3. Effect of rate and method of nutrient application on leaf nitrogen $(N)$ and potassium (K) concentration of 'Gala' and 'Fuji' apples (Rombolà et al., unpublished).

\begin{tabular}{lcc}
\hline Parameter & $\begin{array}{c}\text { Leaf } \mathbf{~} \\
\text { (\% dry wt) }\end{array}$ & $\begin{array}{c}\text { Leaf K } \\
\text { (\% dry wt) }\end{array}$ \\
\hline Cultivar & & 1.10 \\
$\quad$ Mondial Gala & 2.35 & 0.97 \\
$\quad$ Fuji & 2.60 & $* * *$ \\
$\quad$ Significance & $* * *$ & $0.98 \mathrm{~b}$ \\
Treatment & & $1.10 \mathrm{a}$ \\
$\quad$ Conventional (N-P-K) full rate & $2.55 \mathrm{a}^{z}$ & $1.09 \mathrm{a}$ \\
Fertigation $(\mathrm{N}-\mathrm{P}-\mathrm{K})$ full rate & $2.58 \mathrm{a}$ & $* * *$ \\
$\quad$ Fertigation $(\mathrm{N}-\mathrm{P}-\mathrm{K})$ half rate & $2.40 \mathrm{~b}$ & $\mathrm{NS}$ \\
$\quad$ Significance & $* * *$ & $\mathrm{NS}$ \\
$\quad$ Cultivar $\times$ treatment & &
\end{tabular}

${ }^{\mathrm{z}}$ Mean separation by Student-Newman-Keuls' test $(P=0.05)$

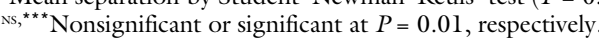

improving fruit external quality appearance (Scudellari et al., 1998 a), although penetration of Monilia laxa (the causal agent of brown rot) was not prevented (Quartieri et al., 2000).

Recent evidence obtained in apple orchards in the Po Valley on soils well endowed with $\mathrm{Ca}$ (Zavalloni et al., 2001), indicates that fruit partitioning of root absorbed Ca is not limited to a short 4- to 6-week period after full bloom but rather occurs throughout the season including close to fruit harvest.

A predictive test for bitter pit in apples has been developed by the South Tyrolean Advisory Service for Fruit and Wine Growing and by the Research Station of Laimburg. The test includes sampling fruitlets when their fresh weight is 50 to $70 \mathrm{~g}$ ( 1.76 to 2.47 $\mathrm{oz})$, analyzing their mineral concentration and estimating the $\mathrm{K} / \mathrm{Ca}$ fruit ratio at harvest on the basis of prediction models (Drahorad and Aichner, 2001). Although a variety of Ca-based compounds have been tested, calcium chloride and calcium nitrate are still considered the most efficient products; the number of Ca sprays suggested vary from 1 to 2 on 'Gala' to 6 to 8 on 'Braeburn' (Drahorad, 1999).

IRON. A significant part of the fruit tree industry in the Po Valley area is located on calcareous or alkaline soils that favor the occurrence of Fe chlorosis. This is likely the main nutritional constraint in growing peach, pear and kiwifruit plantings in this region. Chlorosis causes severe yield reduction (Tagliavini et al., 2000). If pear tree trees, for example, exhibit chlorosis symptoms at bloom, fruit set and yields are compromised and trees are likely to fall into biennial bearing.
Fruits from chlorotic plantings may also have poor internal quality, less sugar and reduced acid content. Chlorotic symptom also vary from year to year as a result of several tree and environmental variables, including heavy yields, low temperature and high precipitation. Iron chlorosis may be more severe than expected on the basis of soil $\mathrm{pH}$ and the concentration of $\mathrm{CaCO}_{3}$ if soil has a poor structure (e.g., due to compaction) and is saturated with water and if $\mathrm{HCO}_{3}$ concentration increases around the roots. Soil management may also affect chlorosis development and symptoms are usually less severe if the orchard floor is grassed than if it is cultivated, a fact generally attributed to a mechanical damage of shallow roots resulting from cultivation.

Although the best way to avoid chlorosis in fruit trees is likely to choose

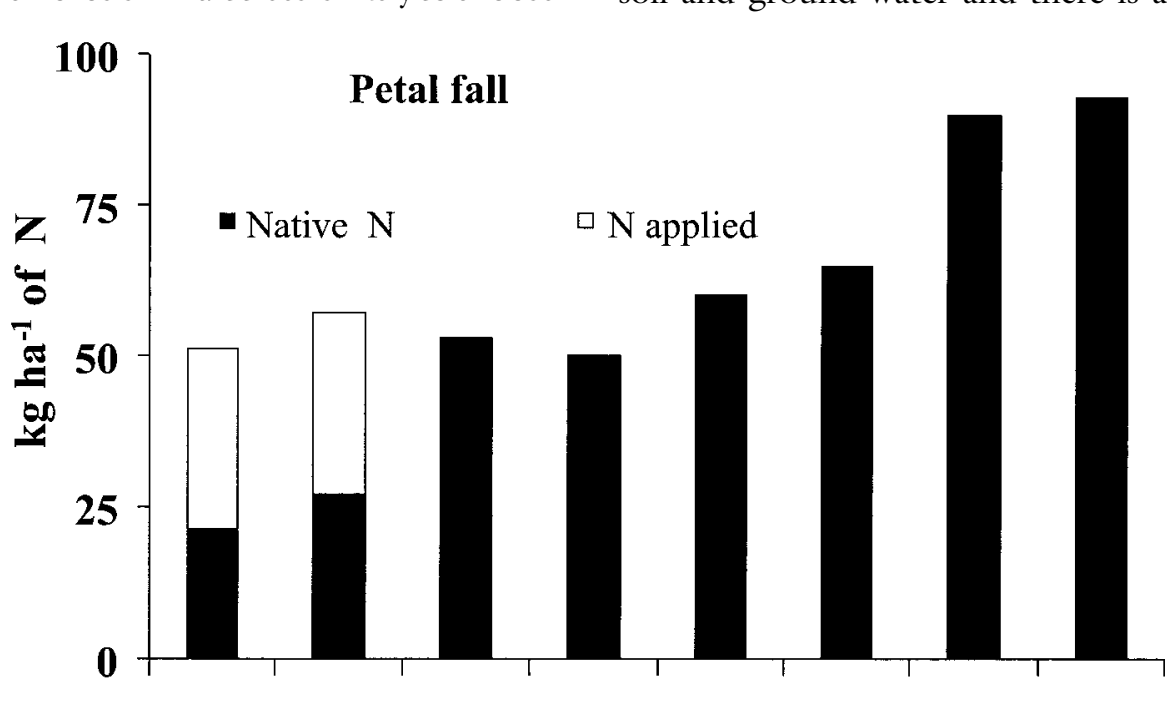

\section{Pear orchards}

Fig. 1.Example of soil N availability in 'Abbé fetel' pear orchards in the Emilia Romagna region of Italy at petal fall stage. Open bars represent amounts applied; solid bars represent native soil $\mathrm{N} ; 1 \mathrm{~kg} \cdot \mathrm{ha}^{-1}=0.891 \mathrm{~b} / \mathrm{acre}$. 


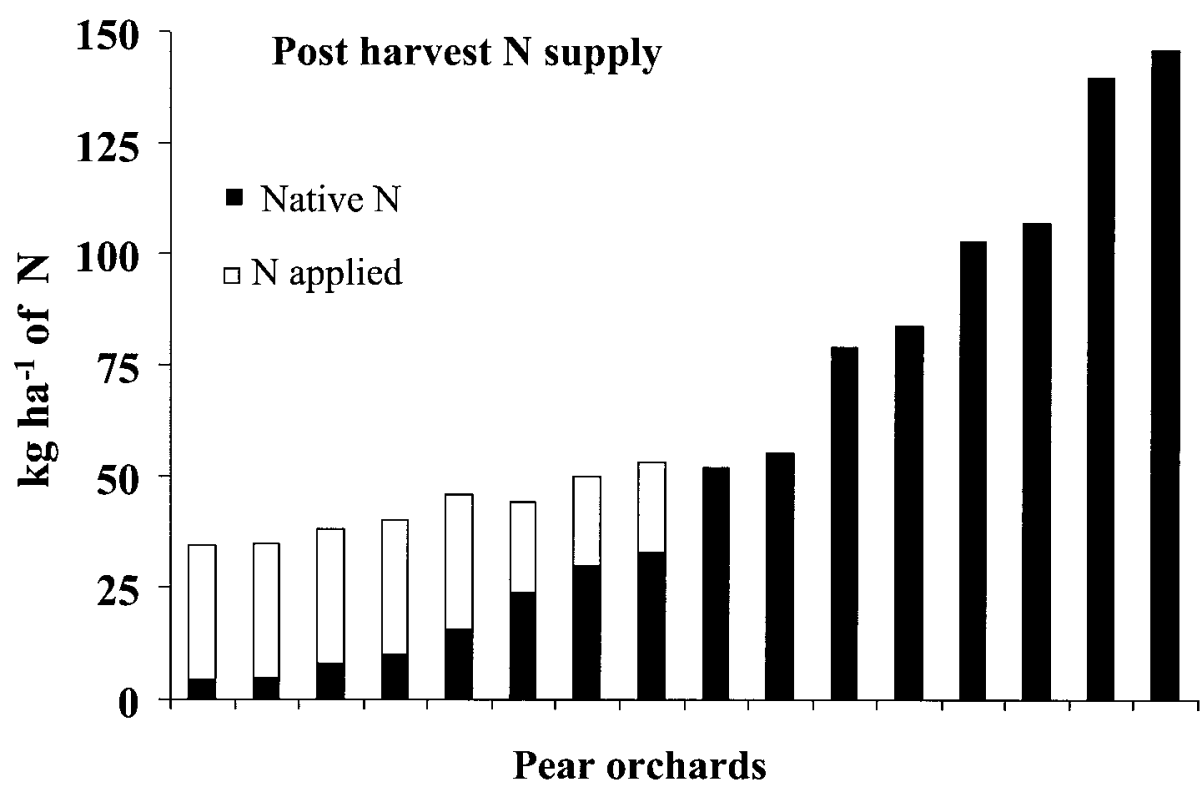

Fig. 2. Example of soil nitrogen $(N)$ available for tree uptake in 'Abbé fetel' pear orchards in the Emilia Romagna region of Italy before postharvest $\mathrm{N}$ supply. Open bars represent amounts applied; solid bars represent native soil $\mathrm{N}$; $1 \mathrm{~kg} \cdot \mathrm{ha}^{-1}$ $=0.89 \mathrm{lb} /$ acre .

need for reliable alternatives to Fe chelates. This may be achieved by enhancement of soil Fe availability (e.g., through the addition of organic matter composted with Fe salts, the presence of phytosiderophore releasing grasses, or the amelioration of soil structure) through the reduction of rhizosphere and soil $\mathrm{pH}$ (by switching from nitrate- $\mathrm{N}$ to ammonium- $\mathrm{N}$ nutrition). Iron availability in the leaves might be increased by lowering apoplast $\mathrm{pH}$ by sprays of acid compounds (Tagliavini et al., 2000).

\section{Application technology}

Technology related to products and application techniques has been changing in orchards in north Italy. An increasing number of growers is adopting fertigation as the primary way to supply nutrients in order to reduce fertilizer application rates by enhancing the efficiency of fertilizer use. Solutions adopted vary from inexpensive adaptation of preexisting drip irrigation systems, to computer controlled systems. A large number of companies on the market sell either pure and highly soluble salts (e.g., potassium nitrate, urea-phosphate, monoammonium phosphate, monopotassium phosphate, potassium sulphate, etc.) or premixed products in soluble, ready to use, forms. Fertigation often requires lowering the $\mathrm{pH}$ of the solution to avoid precipitation of salts within the lines. Depending on

\section{Monitoring and testing}

Leaf diagnosis. Major progress in leaf diagnosis has been achieved through studies at the Istituto Agrario $S$. Michele a Adige in cooperation with the University of Milan (Failla et al., 1993, 2001) and by the Laimburg Experiment Station. The results obtained from thousands of leaf analyses resulted in the development of local standards for leaf analysis interpretation, and criteria for certification of low input fertilization strategies and agroecological evaluation and zoning. Preliminary reference standards for leaf nutrients for pear and peach have been obtained in the Po Valley (Scudellari et al., 1999; Toselli et al., 2001). Major work is also needed to standardize sample digestion and analysis procedures so that results from different laboratories can be readily compared. Main objectives in the future include determination of indices for early diagnosis (early summer or spring) and the possible development of new analytical and diagnostic tools (e.g., not destructive, ready to use and inexpensive methods).

Soll MONITORING. A monitoring procedure for assessing soil $\mathrm{N}$ availability has been developed (Tagliavini et al., 1994) and tested (Scudellari et al., 1998b, 2000). The basic idea of the procedure is to use data to integrate information of amount and kinetics of $\mathrm{N}$ uptake so that growers will only apply the difference between actual tree $\mathrm{N}$ needs and amounts available in orchard soil. Several preliminary trials indicated that under our conditions, almost all $\mathrm{N}$ is present in the root zone in the form of nitrate while ammonium concentration is negligible. The method includes 1) soil sampling prior to timings designated for $\mathrm{N}$ fertilization (e.g., in peach, flowering, fruit thinning, postharvest) from zones of most intense root development;2) extraction and determination of nitrate-N; 3 ) conversion of nitrate concentration to amounts of available N per hectare and 4) recommendation of orchard $\mathrm{N}$ fertilizer needs. By this procedure $\mathrm{N}$ mineralization occurring after soil collection is not accounted for, so slight overestimation of $\mathrm{N}$ needs in spring can occur. This, however, can be compensated by lower $\mathrm{N}$ recommendations later in the season. The adoption of this method in pear orchards has restricted the $\mathrm{N}$ supply only 
to situations of real need (Figs. 1 and 2 ) and theoretically can minimize any residual $\mathrm{N}$, likely subjected to leaching if present in the soil at the end of the season.

\section{Final remarks and outlooks}

Current trends are for restriction in the amounts of mineral nutrients to be applied in orchards, resulting from increasing regulation at the European Union and local level. This will encourage better use of technology for supplying nutrients that will in turn only be achieved by specific research projects. Monitoring nutritional status will become crucial for adjusting nutrient supply to avoid unnecessary applications as well as to avoid the development of nutrient deficiencies. New, rapid and inexpensive monitoring techniques both for soil and trees should be developed. Major research is needed for optimizing the use of natural resources for mineral nutrients within the orchard ecosystem, including abscised leaves, pruning wood, mowed grasses, $\mathrm{N}$-fixing bacteria and mycorrizhae, or from beyond the orchard, compost, sewage sludge, etc. Current research projects should also focus on the availability of nutrients under organic farming and on the interactions between nutrition and tree pathogens and pests.

\section{Literature cited}

Drahorad, W. 1999. Modern guidelines on fruit tree nutrition. Compact Fruit Tree 32(3):91-96.

Drahorad, W. and M. Aichner. 2001. Development and evaluation of a bitter pit prognosis model in apple orchards in the South Tyrol (Italy). Proc. 5th Intl. Symp. Mineral Nutrition of Deciduous Fruit Crops. Penticton, Canada, Aug. 2000. Acta Hort. (in press).

Failla, O., Stringari, G., Porro, D., and A. Scienza. 1993. Determination of leaf standards for apple trees and grapevines in northern Italy, p. 37-41. In: M.A.C. Fragoso, M.L. Van Beusichem, and A. Houwers (eds.). Optimization of plant nutrition. Kluwer Academic Publishers, Dordrecht, Netherlands.

Failla., O., S. Santucci, C. del Turco, L. Di Francesco, and I. Chiuchiarelli. 2001. Tree nutritional status in relation to soil pedogenetic desciption: a case study. Proc. 5th Int. Symp. Mineral Nutrition of De- ciduous Fruit Crops. Penticton Canada August 2000. Acta Hort. (in press).

Quartieri, M., M. Siroli, C. Zavalloni, C. Ceredi, C. Lugaresi, B. Marangoni, and M. Tagliavini. 2000. Miglioramento qualitativo delle nettarine e controllo della monilia mediante metodi agronomici e chimici, p. 127-131. In: S. Sansavini (ed.). Atti XXIII Convegno Peschicolo, Ravenna, Sept. 1997.

Regione Emila Romagna. 1994. I suoli dell'Emilia Romagna. Note illustrative. Bologna, Italy.

Rombolà, A.D., C. Zavalloni, D. Scudellari, A. Ceccaroli, F. Mazzanti, B. Marangoni, and M. Tagliavini. 2000. La fertirrigazione del meleto nella fase d'allevamento: effetti di dose e nutrienti. Rivista di Frutticoltura 6:67-74.

Sansavini, S. 1998. The fruit industry in Italy, p. 145-155. In: Italian Horticulture. World Conf. Hort. Res. Rome, 17-19 June.

Sansavini, S., L. Corelli-Grappadelli, G. Costa, S. Lugli, B. Marangoni, M. Tagliavini, and M. Ventura. 1999. Ricostituzione e revisione degli indirizzi produttivi e frutticoli della peschicoltura romagnola. Rivista di Frutticoltura 3:820 .

Scudellari, D., M. Toselli, B. Marangoni, and M. Tagliavini. 1999. La diagnostica fogliare nelle piante arboree da frutto a foglia caduca. Bollettino della Società Italiana di Scienza del Suolo 48(8):829842.

Scudellari, D., G. Spada, C. Zavalloni, B. Marangoni, F. Mazzanti, and I. Mignani. 1998a. Influenza dei trattamenti di calcio alla chioma sulla qualità dei frutti di pesco (cv. Caldesi84). Notiziario tecnico del Centro Ricerche Produzioni Vegetali 54:29-37.

Scudellari, D., M. Tagliavini, B. Marangoni, L. Rubbi, V. Capucci, and F. Pelliconi. 1998 b. Approccio integrato della concimazione azotata del frutteto. Notiziario tecnico del Centro Ricerche Produzioni Vegetali 54:20-28.

Scudellari, D., M. Tagliavini, B. Marangoni, L. Rubbi, V. Cappucci, F. Pelliconi, and G. Marani. 2000. Frutteto, si può migliorare la concimazione azotata. Agricoltura 3:5861.

Socias i Company, R., J. Gomez Aparisi, and A.J. Felipe. 1995. A genetical approach to iron chlorosis in deciduous fruit trees, p. 167-174. In: J. Abadia (ed.). Iron nutrition in soils and plants. Kluwer Academic Publishers, Dordrecht, Netherlands.

Tagliavini, M., J. Abadia, A.D. Rombolà,
A. Abadia, C. Tsipouridis, and B. Marangoni. 2000. Agronomic means for the control of iron deficiency and chlorosis in deciduous fruit plants. J. Plant Nutr. 23(11-12):2007-2022.

Tagliavini, M., A. Masia, and M. Quartieri. 1995. Bulk soil $\mathrm{pH}$ and rhizosphere $\mathrm{pH}$ of peach trees in calcareous and alkaline soils as affected by the form of nitrogen fertilizer. Plant Soil 176:263-271.

Tagliavini, M., P. Millard, and M. Quartieri. 1998. Storage of foliar absorbed $\mathrm{N}$ and remobilisation for spring growth in young nectarine $(P$. persica var. nectarina) trees. Tree Physiol. 18:203-207.

Tagliavini, M., M. Quartieri, and P. Millard. 1997. Remobilised nitrogen and root uptake of nitrate for leaf growth, flowers and developing fruits of pear (P. communis L.) trees. Plant Soil 195:137-142.

Tagliavini, M. and A.D. Rombola. 2001. Iron deficiency and chlorosis in orchard and vineyard ecosystems. Euro. J. Agron. 15:71-92.

Tagliavini, M., D. Scudellari, B. Marangoni, and M. Toselli. 1994. Nitrogen fertilization management in orchards to reconcile productivity and environmental aspects, $\mathrm{p}$. 161-170. In: C. Rodriguez-Barrueco (ed.). Fertlizers and environment. Kluwer Academic Publishers, Dordrecht, Netherlands.

Tagliavini, M., D. Scudellari, B. Marangoni, and M. Toselli. 1996b. Nitrogen fertilization management in orchards to reconcile productivity and environmental aspects. Fert. Res. 43(1-2):93-102.

Tagliavini, M., D. Steffens, and F. Pelliconi. 1996a. La carenza di potassio nei vigneti della romagna. Vignevini 4:41-46.

Toselli, M., J. A. Flore, C. Zavalloni, and B. Marangoni. 2000. Nitrogen partitioning in apple trees as affected by application time. HortTechnology 10(1):6-11.

Toselli, M., D. Scudellari, B. Marangoni, F. Mazzanti, and M. Tagliavini. 2001. Determination of leaf standards for mineral diagnosis in pear orchards of Po Valley. Proc. 8th Int. Pear Symp. Ferrara-Bologna, Italy. Sept. 2000. Acta Hort. (in press).

Zavalloni, C., A.D. Rombolà, M. Belletti, F. Pelliconi, and M. Tagliavini. 1998. Nutrizione del pesco: una tecnica innovativa. Terra e Vita (Suppl.)13:8-11.

Zavalloni, C., B. Marangoni, D. Scudellari, and M. Tagliavini. 2001. Dynamics of uptake of calcium, potassium and magnesium into apple fruit in a high density planting orchard. Proc. 5th Intl. Symp. Mineral Nutrition of Deciduous Fruit Crops. Penticton Canada, Aug. 2000. Acta Hort. (in press). 